\title{
Fine Needle Aspiration Cytology of Kaposi Sarcoma in Lymph Node: A Case Report
}

\section{Lenf Düğümünde Kaposi Sarkomunun İnce İğne Aspirasyon Sitolojisi: Olgu Sunumu}

\author{
Çiğdem Irkkan, Rüçhan Aygün, Fisun Ardıç Yükrük
}

Dr. A. Y. Ankara Onkoloji Eğitim Ve Araştırma Hastanesi, Patoloji Kliniği, Ankara, Türkiye DOI:10.5505/aot.2013.29291

\section{ÖZET}

Daha önce Kaposi Sarkomu tanısı alan bir hastanın tanıdan bir y1l sonra supraklaviküler fossada gelişen lenfadenopatisinden görüntüleme eşliğinde ince iğne aspirasyonu ile örnekleme yapılmıştır. Aspirasyon sitolojisinde büyük doku fragmanları yanısıra daha küçük hücre kümeleri izlenmiştir. Gevşek gruplarda iğsi hücreler yuvarlak-oval nükleuslu, açık mavi renk sitoplazmalı izlenmiş ve Kaposi sarkomu tanısı verilmiştir. Lenf düğümünün Kaposi sarkomu tutulumunda ince iğne aspirasyon sitolojisi bulguları literatür eşliğinde gözden geçirilmiştir.

Anahtar Kelimeler: Kaposi Sarkomu; Lenf Nodu; Biyopsi; İnce-İğne

\begin{abstract}
Image guided fine needle aspiration from the supraclavicular lymph node of a patient with prior Kaposi sarcoma diagnosis was performed. In the aspiration cytology large tissue fragments and small cell clusters were seen. In looser clusters spindle cells with round to oval nuclei with light blue cytoplasms were seen and Kaposi sarcoma diagnosis was given. Fine needle aspiration cytology findings of Kaposi sarcoma in lymph nodes is reviewed with the literature.
\end{abstract}

Key words: Kaposi Sarcoma; Lymph Node; Biopsy; Fine-Needle

\section{Giriş}

Kaposi sarkomu (KS) tipik olarak çoklu nodül ve plaklar şeklindeki deri lezyonları ile karşımıza çıkan lokal agresif bir tümördür. Ülkemizde en s1k klasik-indolent forma rastlanır, ileri yaşta görülür ve lezyonlar genellikle distal ekstremitelerde olup yavaş gidişlidir. Klasik formda lenf dügümü ve viseral tutulum çok nadirdir $(1,2)$.

İnce iğne aspirasyon sitolojisi (IİAS) ucuz ve hizlı bir metod olup, lenfadenopatilerin ilk değerlendirilmesinde yaygın olarak kullanılmaktadır. KS'de lenf dügümü tutulumu, artan KS insidansı ile birlikte daha s1k görülmektedir. KS'de İIAS bulguları patoloji ve sitoloji kitaplarında kisaca yer almaktadır (3-5).

KS'de lenf düğümü tutulumu daha sıklıkla, gençlerde görülen endemik-Afrika formunda ve AIDS ilişkili epidemik formda meydana gelir. Lenf düğümünde KS'nin İ̇AS bulgularının çoğu bu olgulardan elde edilmiştir $(6,7)$. Biz, preAIDS-AIDS ve immünsupresyon hikayesi olmayan, klasik formda KS'li bir olguda lenf düğümü tutulumunda gördüğümüz sitolojik bulguları literatür eşliğinde sunduk.

\section{Olgu Sunumu}

Altmışiki yaşında erkek hastada, sol supraklaviküler fossada (SKF) 12x11 mm boyutlarında, malign radyolojik özellikte lenfadenopati saptand. Sol infraklaviküler fossada $43 \times 26 \mathrm{~mm}$ boyutlarında, heterojen vaskülariteye sahip, lobüle kontürlü, metastaz şüphesi taşıyan ikinci kitle vardı. Bir yıl önce, başka bir merkezde, sol el bileğindeki lezyondan, KS tanısı almış ve HIV negatifti.

SKF'de lenfadenopatiden görüntüleme eşliğinde yapılan İIAS materyalinde, büyük doku fragmanları izlendi (Resim 1). Bazı alanlarda nükleer frajilite nedeniyle şeritler oluşmuştu (Resim 2). Küçük gruplar hücresel detayların iyi izlenebildiği yuvarlak-oval nükleuslu gevşek hücreler içermekteydi (Resim 3). Hücre sitoplazmaları May Grünwald-Giemsa (MGG) ile açık mavi 
izlendi (Resim 4). Globül yapısı görülmedi. Bulgular KS tutulumu olarak raporlandı.

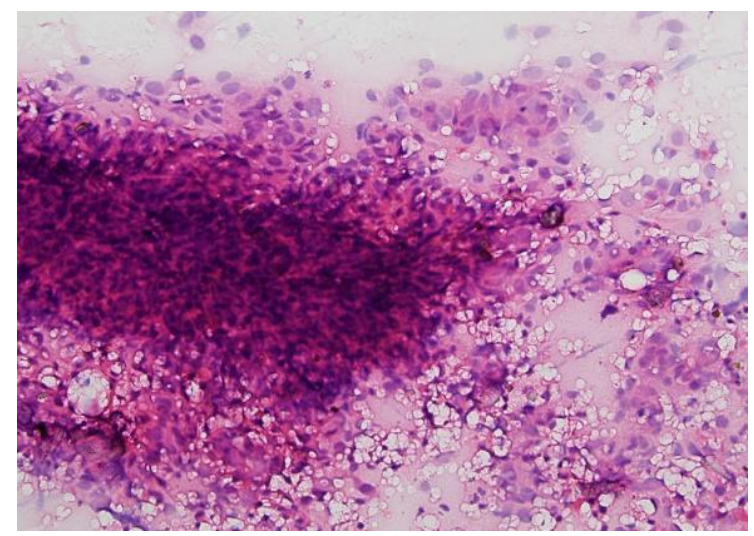

Resim 1: Resim 1. Selüler yayma preperatlarda büyük doku fragmanları (HE, $\mathrm{x} 100$ ).

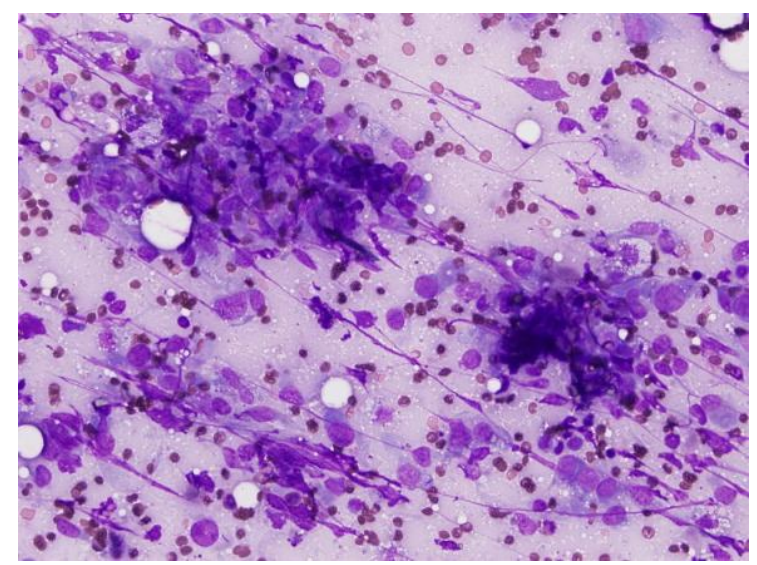

Resim 2: Nükleer frajilite bulgusu (MGG, $\mathrm{x} 200)$.

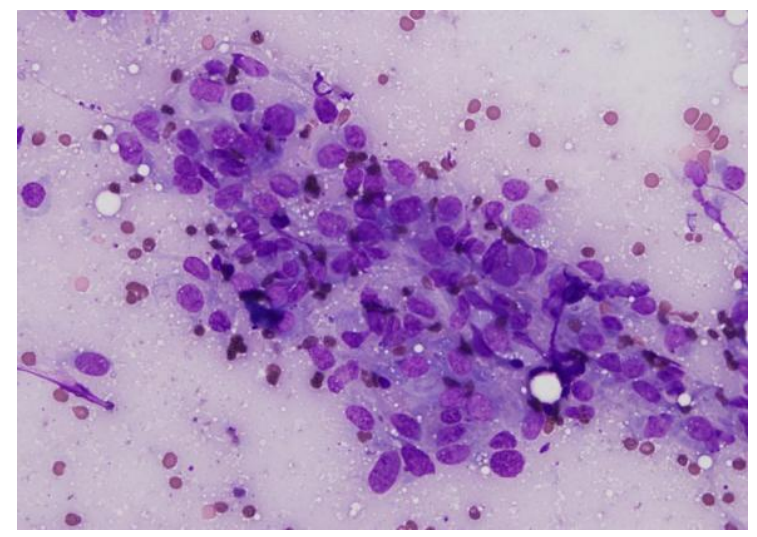

Resim 3. Gevşek gruplarda hücreler (MGG, $\mathrm{x} 200$ ).

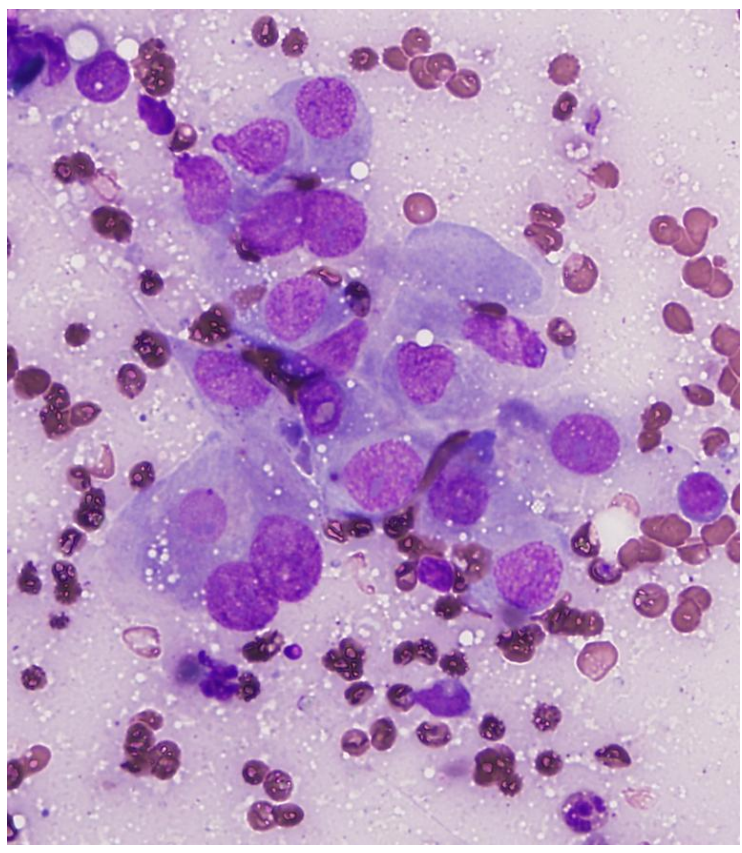

Resim 4: Açık mavi renkte sitoplazmalar (MGG, x400).

Daha sonra 6 aydır sol ön kol ve elde varolan, boyutlar1 $9 \mathrm{~mm}$ ile $22 \mathrm{~mm}$ arasinda değişen üç ayrı lezyon eksize edildi. Histopatolojide deri içermeyen iyi sınırlı nodüller, oval-yuvarlak ya da iğsi şekilli, demetler yapan, sık mitoz içeren, bir ya da birkaç küçük nükleollü, sitoplazmik sınırları seçilemeyen, hafif atipik hücrelerden oluşmaktaydı (Resim 5). İçleri eritrosit dizileri içeren vasküler yarıklardan fakirdi (Resim 6). Fokal nekroz odakları yanısıra yer yer belirgin atipi göze çarpmaktaydı (Resim 6). İmmünohistokimyasal olarak tümör CD31 ve HHV8 (Resim 7) pozitif iken, CD34 ve Faktör 8 negatifti.

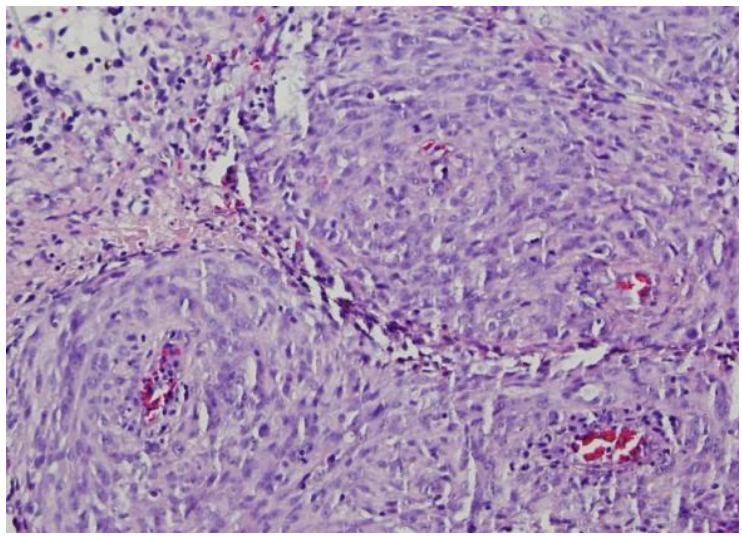

Resim 5: Vasküler yapılar çevresinde demetler oluşturan, hafif atipi ve sik mitoz gösteren hücreler (H\&E, x200). 


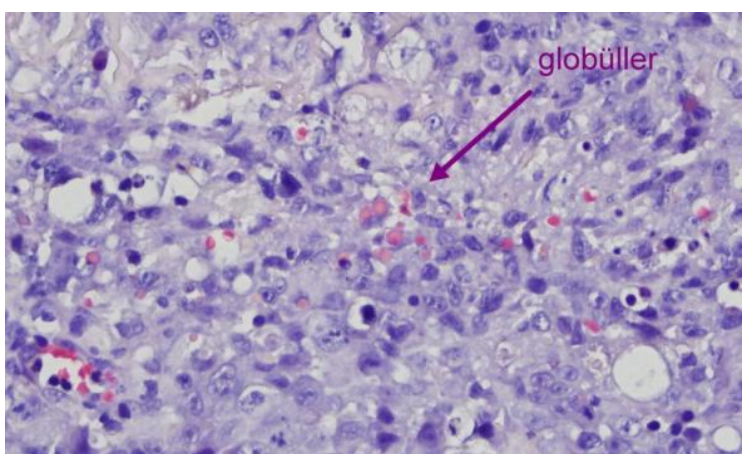

Resim 6: Nadir eozinofilik globül yapıları ve yüksek atipili bir alan (H\&E, x400).

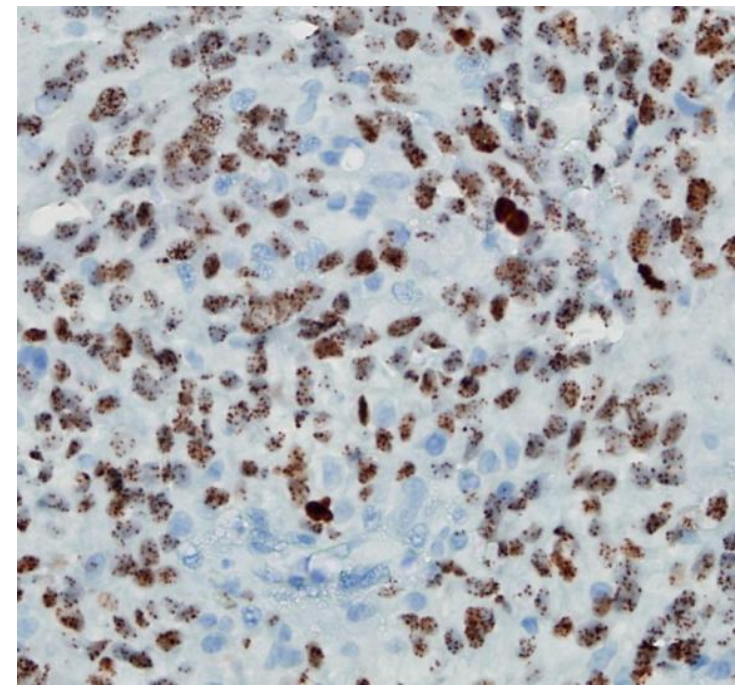

Resim 7: Karakteristik granüler nükleer HHV8 pozitifliği $(x 400)$.

Bundan 3 ay sonra sol el parmaklarında tekrarlayan lezyonlar benzer özellikte izlendi. Hasta daha sonra takiplere gelmedi.

\section{Tartışma}

KS'nin dört farklı klinik ve epidemiyolojik formu vardır. Endemik-Afrika KS'si lenfadenopatik formdadır, hızlı ilerleyen ve ölümcül seyri vardır. atrojenik KS immünsupresif tedavi alan transplantlı hastalarda görülür $(1,2)$. AIDS ilişkili KS en agresiv formdur, HIV1 enfekte kişilerde görülür. Deri tutulumundan başka lenf düğümleri, gastrointestinal sistem ve akciğerler siklıkla tutulur $(1,2)$. Klasik formda lenf düğümü ve viseral tutulum çok nadirdir (1). Biz klasik formda KS'li bir hastada lenf düğümü tutulumu izledik.

KS primer lezyonlarında ince iğne aspirasyonu nadiren yapılmaktadır. KS

Adressforcorrespondence: Uzm. Dr. Cị̆dem Irkkan

e-mali: cirkkan@gmail.com

Available at www.actaoncologicaturcica.com

Copyright @Ankara Onkoloji Hastanesi aspirasyonlarında görülen bulgular, mezenşimal tümörlerin aspirasyonunda görülenlerle benzerdir. Bunlar;

1. Belirsiz sitoplazma sinırları ve frajil nükleuslardan oluşan oval-iğsi hücreli kalın doku fragmanları

2. İnce granüler eşit dağılmış kromatin ve soluk sitoplazmalı küçük gevşek hücre kümeleri

3. Kanlı zemin

4. Doku fragmanlarında hücrelerin radyal dizilimleri

5. Doku fragmanlarında içi eritrosit dolu vasküler boşluk benzeri yarıklar

6. Metakromatik stroma olarak tarif edilmiştir (3).

KS'de doku kesitlerinde görülen eozinofilik globüller, IİAS'lerde genellikle izlenmemiştir (3). Bir olguda lenf düğümü tutulumunda nadir böbrek şekilli nükleuslara dikkat çekilmektedir (8). Olgumuzun aspirasyon örneğinde gördüğümüz oval-iğsi hücreli kalın doku fragmanları (Resim 1) ve daha küçük gevşek hücre grupları (Resim 3,4$)$, lezyonun mezenşimal kaynaklı olduğunu düşündürmüştür. $\mathrm{Bu}$ bulgular düşük dereceli başka sarkomlarda da görebileceğimiz özellikteydi ve KS için spesifik başka bir bulgumuz yoktu. Eozinofilik globülleri ve böbrek şekilli hücreleri de izlemedik. Ancak olgumuzda klinik hikaye bilindiğinden, İİAS tanısal olmuştur. Klinik hikaye bilinmediğinde bu bulgularla kesin olarak KS tanıs1 verilmemeli, biyopsi ile doğrulanmalıdır.

Klinik hikaye bilindiğinde veya desteklediğinde sitolojik materyalde PCR (polimerase chain reaction) veya hücre bloğunda immünhistokimya ile HHV-8 gösterilmesi tanısal olup gereksiz biyopsi önlenebilmektedir (2,3). Nadir de olsa AIDS şüphesi olanlar ve homoseksüel erkeklerde cilt lezyonları olmaksızın, lenf düğümü tutulumu geliştiğinde İIAS ile KS saptanarak AIDS tanısını desteklemektedir $(9,10)$.

Olgumuzda lenf dügümlerinin ana vasküler yapılara yakın yerleşiminden dolayı eksizyonel biyopsi yapılmayıp, hasta takipte bırakılmıştır. KS multifokal bir gelişim olup, lenf düğümünde görüldüğünde bunun başl1 başına bir gelişim oldup, metastaz olmadığını kabul eden görüșler vardır (6).

Ayırıcı tanıda bir çok benign ve malign iğsi hücreli lezyon yer almaktadır. Granülasyon dokusu; içerdiği inflamatuar 
hücreler ve dallanan kapiller yapılar ile KS'den ayrılır. Reparatif dokular; daha iri pleomorfik ve büyük nükleollü hücreleri ile ayrilır. Epiteloid histiyositler; daha geniş sitoplazmaları ve daha iğsi şekilleriyle, anjiosarkom ise şiddetli atipi ve makronükleolleri ile KS'den ayrılır (11).

CD34, KS'nin en iyi belirteci olmakla birlikte reaktivitesi değişkenlik gösterebilmektedir (12,13). Olgumuzda lezyonların agresif geç evre ile uyumlu histomorfolojide olmas1 ve CD34 ekspresyonu göstermemesi, ayırıcı tanıda düşük dereceli anjiosarkomun ekarte edilmesini gerektirmiştir.

\section{Referanslar}

1) Fletcher CDM, Bridge JA, Hogendoorn PCW, Mertens $F$ eds. World Health Organization classification of tumours of soft tissue and bone, 4th edn. Lyon: IARC Press; 2013:151-2

2) Radu O, Pantanowitz L. Kaposi Sarcoma. Arch Pathol Lab Med 2013;137:289-94

3) Czerniak B, Tuziak T. Soft tissue lesions. In Koss LG and Melamed MR eds, Koss's Diagnostic Cytology and its histologic bases. Fifth ed. Lippincott, Williams Wilkins 2006; 1322

4) Lin O, Zakowski MF. Cytology of Soft Tissue, Bone, and skin. in Bibbo $\mathrm{M}$ and Wilbur D. eds. Comprehensive Cytopathology, 3rd edn, Philadelphia: Saunders Elsevier; 2008: 484

5) Wakely PE, Cibas ES. Lymph Nodes. In Cibas ES Ducatman BS eds. Cytology Diagnostic Principles and Clinical Correlates. $3^{\text {rd }}$ ed. Philadelphia, Saunders, 2009; 354

6) Ioachim HL, Medeiros LJ. Kaposi Sarcoma. In Ioachim HL, Medeiros LJ eds. Ioachim's Lymph
Ancak hasta yaşı, hikayesi, lezyonların yerleşimi, çoklu oluşları, FVIII negatifliği, HHV8 pozitifliği, anastomozlaşan kanal ve endotel döşeli yarıkların bulunmayışı KS'yi desteklemiştir.

Günlük pratikte s1k gördüğümüz $\mathrm{KS}$, karşımıza nadiren sitolojik materyal olarak da çıkabilmektedir. Sitoloji materyalinde bulgular spesifik olmayıp, hikaye yol göstericidir.

\section{Çıkar Çatışması:Yok}

node pathology 4th ed. Philadelphia: Lippincott Williams Wilkins; 2009:581-2

7) al-Rikabi AC, Haidar Z, Arif M, al-Ajlan AZ, Ramia S. Fine-needle aspiration cytology of primary Kaposi's sarcoma of lymph nodes in an immunocompetent man. Diagn Cytopathol 1998;19:451-4

8) Fulciniti F, De Chiara A, Apice G, et al. Fine-Needle Cytology of Kaposi's Sarcoma in an Intramammary Lymph node: Report of One Case. Diagn Cytopathol 2012;40 Suppl 2:E149-52

9) Morelli L, Pusiol T, Piscioli I, Del Nonno F, Brenna A, Licci S. Fine needle aspiration cytology determinants of the diagnosis of primary nodal Kaposi's sarcoma as the first sign of unknown HIV infection: a case report. Acta Cytol 2007;51:602-4

10) Gagliano EF. Fine needle aspiration cytology of Kaposi's sarcoma in lymph nodes. A case report. Acta Cytol 1987;31:25-8 